\title{
Study of antimicrobial potential and cytotoxic of Cordia nodosa species
}

\author{
Raíssa Fernanda Evangelista Pires dos Santos ${ }^{1^{*}}$, Isabelle Souza de Mélo Silva Silva ${ }^{2}$, Lukas Reis d'Costa ${ }^{2^{*}}$, \\ Andriele Mendonça Barbosa², Klebson Santos Silva², Mariene Ribeiro Amorim² ${ }^{2}$ Fernando Mendonça Diz ${ }^{2}$, \\ Thais Honório Lins ${ }^{1}$, Regina Célia Santos Sales Verissimo', Francine Ferreira Padilha², \\ Eliane Aparecida Campesatto ${ }^{3}$, Maria Lysete de Assis Bastos ${ }^{1}$ \\ From 5th Congress of the Brazilian Biotechnology Society (SBBIOTEC) \\ Florianópolis, Brazil. 10-14 November 2013
}

\section{Background}

Increasingly infectious agents change, which is why there is a failure in the treatment of microbial infections, above all, the emergence of resistance to existing antibiotics [1]. Therefore, the search for new antimicrobial substances from natural products has increased the interest of researchers. Brazil is considered the country has one of the greatest biodiversity on the planet, where the popular use of medicinal plants has become an important source for discovery of new active compounds [2]. However, for the safe use of these plant species, popular knowledge must relate to the performance of bioassays that demonstrate the therapeutic efficacy and low toxicity. Cordia species belonging to the family Boraginaceae, are used in folk medicine to treat gastric ulcers and proven front possess antimicrobial potential Escherichia coli and Staphylococcus aureus [3]. Phytochemical studies carried out with species of this family revealed the presence of alkaloids, naphthoquinones, saponins, tannins, flavonoids, among others, responsible for this spectrum of biological activities. Cordia nodosa specie has proven antifungal activity but the work as they relate to the antibacterial activity are scarce [4]. The aim of this study was to evaluate the antimicrobial activity and toxicity of Cordia nodosa.

\footnotetext{
'Laboratório de Pesquisa em Tratamento de Feridas, Universidade Federal de Alagoas, Campus A.C. Simões - Av. Lourival Melo Mota, s/n, Cidade Universitária - Maceió, Alagoas, 57072-900, Brazil

${ }^{2}$ Instituto de Tecnologia e Pesquisa, Universidade Tiradentes - Av. Murilo

Dantas, Farolândia - Aracaju, Sergipe, 49032-490, Brazil

Full list of author information is available at the end of the article
}

\section{Methods}

The experimental research was conducted in the Research Laboratory of Wound Care, Federal University of Alagoas. Four fractions were tested in different parts of Cordia nodosa, A, B, C and D. Antimicrobial activity was determined by microbial sensitivity tests, the method of disk diffusion (DD) and broth microdilution method for determination of minimum inhibitory concentration (MIC). The percentage inhibition of bacterial disk diffusion test was calculated by dividing the average inhibition hundred times the sample by the average zone of inhibition positive control [5]. 8 were used bacterial strains, among them Gram-positive and Gram-negative bacteria, distributed by American Type Cell Collection. The toxicity evaluation of the samples was measured by testing toxicity on Artemia salina.

\section{Results and conclusions}

Samples B and C were considered moderately active against the strain of Staphylococcus aureus, with a percent inhibition of $29.2 \%$ (inhibition $=8 \mathrm{~mm}$ ) and $55.6 \%$ (inhibition $=15 \mathrm{~mm}$ ), respectively, when compared with the mean of the positive control used Gentamicin (about $27 \mathrm{~mm}$ ). Both samples were also moderately active against the strains of $S$. epidermidis, involving inhibition percentages of $33.4 \%$. The sample $\mathrm{C}$ presented little active front of the line of $P$. aeruginosa as the percentage of inhibition was less than $25 \%$. The results obtained with the MIC determination showed that the sample B is the fraction of better antimicrobial activity inhibiting the growth of the strain of S. epidermidis concentration of 1000 to $125 \mathrm{mg} \mathrm{mL}^{-1}$. Identified the absence of toxicity in all samples, because the mortality of Artemia salina was $\leq 30 \%$. This finding dismissed the test quantitative, 
and therefore the $\mathrm{LC}_{50}$ determination, because it means that the concentrations tested were below the $\mathrm{LC}_{50}$ of each sample $\left(\mathrm{LC}_{50} \geq 1000 \mathrm{mg} \mathrm{mL}^{-1}\right)$. These results represent the first evidence of safety of plant species that are performed in sequence in vivo bioassays.

\section{Acknowledgements}

Brazilian Ministry of Science and Technology, Federal University of Alagoas, Tiradentes University.

\section{Authors' details}

'Laboratório de Pesquisa em Tratamento de Feridas, Universidade Federal de Alagoas, Campus A.C. Simões - Av. Lourival Melo Mota, s/n, Cidade Universitária - Maceió, Alagoas, 57072-900, Brazil. ${ }^{2}$ Instituto de Tecnologia e Pesquisa, Universidade Tiradentes - Av. Murilo Dantas, Farolândia - Aracaju, Sergipe, 49032-490, Brazil. 'aboratório de Farmacologia e Imunidade, Universidade Federal de Alagoas, Campus A. C. Simões - Av. Lourival Melo Mota, s/n, Cidade Universitária - Maceió, Alagoas, Brasil.

Published: 1 October 2014

\section{References}

1. Sánchez JS: Resistencia a antibióticos. Rev Latino Americana de microbiologia 2006, 48(2):105-112.

2. Pereira $A A$, Cardoso $M G$, Abreu LR, Morais $A R$, Guimarães $L G$, Salgado APSP: Caracterização química e efeito inibitório de óleos essenciais sobre o crescimento de Staphylococcus aureus e Escherichia coli. Ciência Agrotécnica 2008, 32:887-893.

3. Matias EFF, Santos KKA, Almeida TS, Costa JGM, Coutinho HDM: Atividade antibacteriana In vitro de Croton campestris A. Ocimum gratissimum L. e Cordia verbenacea DC. R. bras. Bioci; 2010:8(3):294-298, Porto Alegre.

4. Sousa FCF, Melo CTV, Citó COM, Félix FHC, Vasconcelos SMM, Fonteles MMF, Barbosa Filho JM, Viana GSB: Plantas medicinais e seus constituintes bioativos: Uma revisão da bioatividade e potenciais benefícios nos distúrbios da ansiedade em modelos animais. Revista Brasileira Farmacognosia 2008, 18:642-654.

5. Déciga-Campos M, Rivero-Cruz I, Arriaga-Alba M, Castañeda-Corral G, Angeles-López GE: Acute toxicity and mutagenic activity of Mexican plants used in traditional medicine. J Ethnopharmacol 2007, 110:334-342.

doi:10.1186/1753-6561-8-S4-P69

Cite this article as: dos Santos et al: Study of antimicrobial potential and cytotoxic of Cordia nodosa species. BMC Proceedings 2014 8(Suppl 4):P69.

\section{Submit your next manuscript to BioMed Central and take full advantage of:}

- Convenient online submission

- Thorough peer review

- No space constraints or color figure charges

- Immediate publication on acceptance

- Inclusion in PubMed, CAS, Scopus and Google Scholar

- Research which is freely available for redistribution

Submit your manuscript at www.biomedcentral.com/submit
Ciomed Central 